GSA Data Repository 2016034

\title{
A late Holocene onset of Aboriginal burning in southeastern Australia
}

Authors: Eric W. Portenga ${ }^{1,2} *$, Dylan H. Rood ${ }^{3,4}$, Paul Bishop ${ }^{1,5}$, Paul R. Bierman ${ }^{6}$

${ }^{1}$ School of Geographical and Earth Sciences, University of Glasgow, Glasgow G12 8QQ, UK.

${ }^{2}$ Department of Environmental Sciences, Macquarie University, North Ryde, NSW 2109, Australia.

${ }^{3}$ Department of Earth Science and Engineering, Imperial College London, South Kensington Campus, London SW7 2AZ, UK.

${ }^{4}$ Scottish Universities Environmental Research Centre, University of Glasgow, East Kilbride G75 0QF, UK.

${ }^{5}$ Faculty of Education and Arts, Australian Catholic University, Strathfield, NSW 2315, Australia.

${ }^{6}$ Department of Geology and Rubenstein School of the Environment and Natural Resources, University of Vermont, Burlington, VT 05405, USA.

*Correspondence to: eric.portenga@glasgow.ac.uk

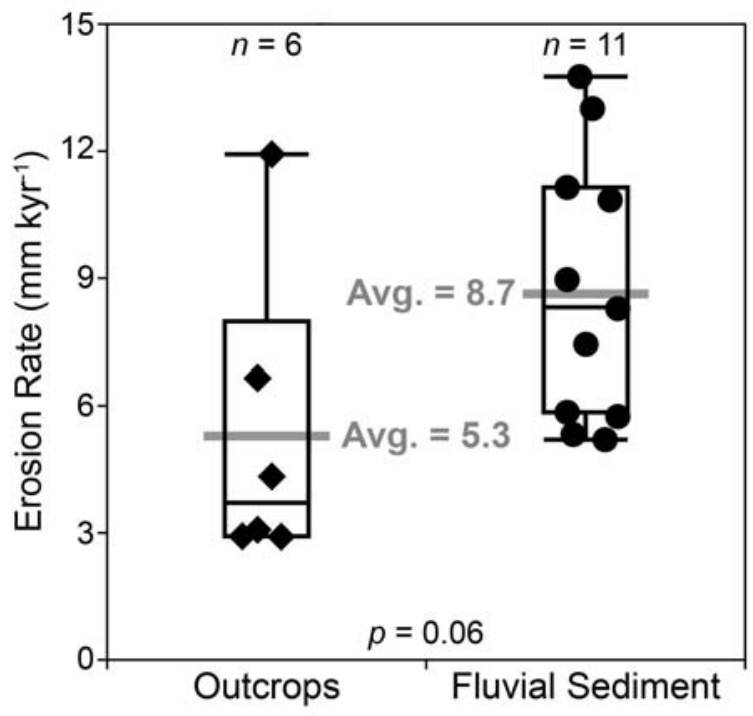

Supplementary Figure DR1. Comparison of outcrop $(\bullet)$ and fluvial sediment $(\bullet)$ erosion rates. Similarity between the average of each sample population is demonstrated by a pooled $t$-Test, assuming equal variances in each sample population (outcrop variance $=10 \mathrm{~mm} \mathrm{kyr}^{-1}$; fluvial sediment variance $=9 \mathrm{~mm} \mathrm{kyr}^{-1}$ ) $(\mathrm{JMP}$ statistics software package, version 12.1). Whiskers are data range and black lines are the 25 th, 50th, and 75 th percentile. 


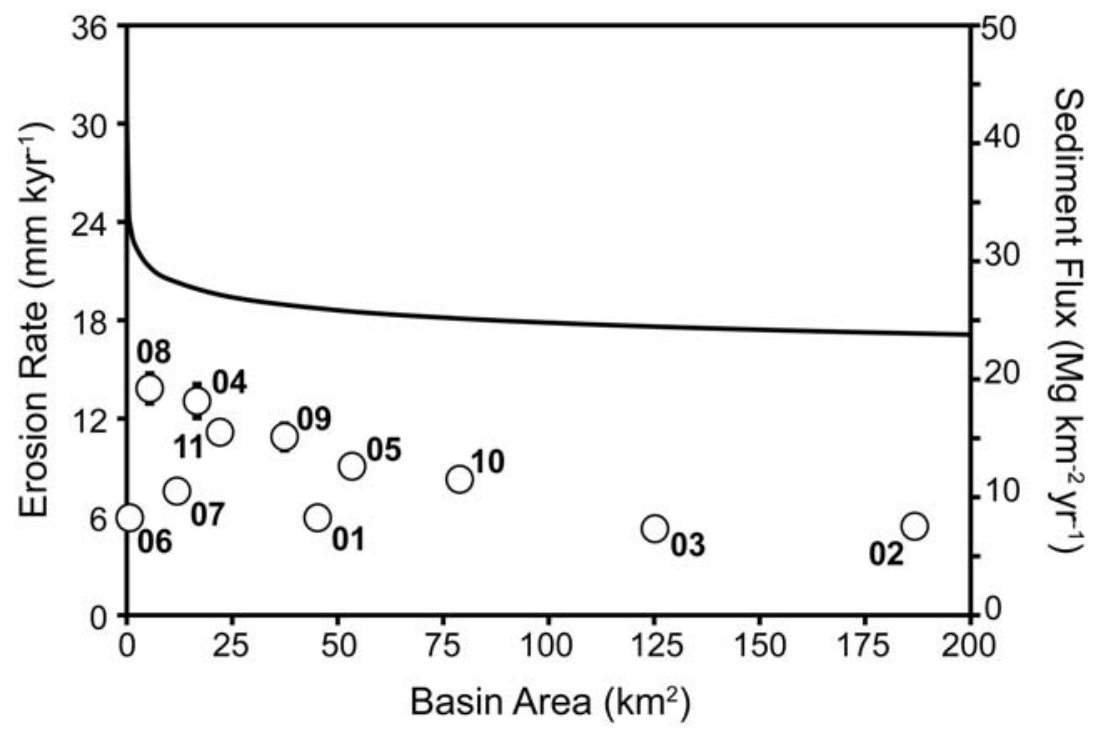

Supplementary Figure DR2. Erosion rates and sediment fluxes derived from fluvial sediment erosion rates are shown as a function of upstream catchment area (data in Table DR2). Numbered labels are sample names, TLBxx. Error bars represent $1 \sigma$ uncertainties; unseen error bars are smaller than the white circles. Solid black line represents estimated post-European sediment fluxes for the Tablelands (Wasson, 1994). Vertical axes are scaled to each other assuming a rock density of $2.7 \mathrm{~g} \mathrm{~cm}^{-3}$.

\section{Details on Modelling the Effects of Aboriginal Burning with ${ }^{10} \mathrm{Be}$}

We model ${ }^{10} \mathrm{Be}$ inventories in fluvial sediment under Aboriginal fire regimes, for a range of background erosion rates. The average rock erosion rates in the Tablelands range from $5 \mathrm{~mm} \mathrm{kyr}^{-1}$ to $10 \mathrm{~mm} \mathrm{kyr}^{-1}$ in this study (Bishop, 1985; Bishop and Goldrick, 2000). We run our model on each of these values to guide our interpretation of model results. We also run the model using the ${ }^{10} \mathrm{Be}$ average erosion rate from fluvial sediment of $8.7 \mathrm{~mm} \mathrm{kyr}^{-1}$. Our model varies the duration over which Aboriginal burning is administered to the Tablelands landscape, perturbing erosion and changing the inventory of ${ }^{10} \mathrm{Be}$, and it assumes that the introduced burning regime remains in constant use through to the present time. We then compare predicted ${ }^{10} \mathrm{Be}$ concentrations with observed ${ }^{10} \mathrm{Be}$ concentrations to assess the timing and effects of Aboriginal fire use.

\section{The starting condition: Nuclide inventories at secular equilibrium}

The starting condition for our nuclide concentration model at time, $t=0$ years after Aboriginal burning begins, presumes that soil thickness $(z)$ in the Tablelands is a constant $\sim 100 \mathrm{~cm}$ (e.g. $z_{t=0}=100 \mathrm{~cm}$ ) (Fifield et al., 2010; Heimsath et al., 2002), and we make the common assumption that ${ }^{10} \mathrm{Be}$ concentrations are in secular equilibrium with respect to surface ${ }^{10} \mathrm{Be}$ production, radioactive decay, and erosion. The nuclide production rate $\left(P_{N}\right.$; atoms $\left.\mathrm{g}^{-1} \mathrm{yr}^{-1}\right)$ in a Tablelands soil profile before Aboriginal burning begins at any depth $(d)$ is given by the equation:

$P_{N}=P_{0} e^{\left(\frac{-d \rho}{\Lambda}\right)}$

where $P_{0}$ is the local surface nuclide production rate $\left(7.19\right.$ atoms $\left.\mathrm{g}^{-1} \mathrm{yr}^{-1}\right)$, scaled from a reference global production rate at sea level and high latitude $\left(4.49 \pm 0.39\right.$ atoms $\left.\mathrm{g}^{-1} \mathrm{yr}^{-1} ; 1 \sigma\right)$, incorporating muogenic production, to an average Tablelands elevation of $750 \mathrm{~m}$ above sea 
level at $35^{\circ} \mathrm{S}$ using the CRONUS online cosmogenic calculator (wrapper script version 2.2, main calculator version 2.1, objective function version 2.0, constants version 2.2.1, muons version 1.1; Balco et al. 2008) and the Lal/Stone scaling scheme polynomials (Lal, 1991; Stone, 2000). $\Lambda$ is the attenuation depth $\left(160 \mathrm{~g} \mathrm{~cm}^{-2}\right)$ (Balco et al., 2008). Because we presume that soils in the Tablelands are $\sim 100 \mathrm{~cm}$ deep before the onset of Aboriginal burning, $\rho=\rho_{\text {soil }}=1.4 \mathrm{~g} \mathrm{~cm}^{-3}$ (the average of soil densities derived from sandstone and granite bedrock; Fifield et al., 2010; Heimsath et al., 2006) is used in Equation (1) for depths $0 \mathrm{~cm}<d<100 \mathrm{~cm}$. We take the density of rock $\left(\rho_{\text {rock }}\right)$ to be $2.7 \mathrm{~g} \mathrm{~cm}^{-3}$; however, the effective density at depths greater than the soil depth $\left(\rho_{d>\text { soil }}\right)$ is the fractional sum of $\rho_{\text {soil }}$ and $\rho_{\text {rock }}$ in the overlying material of the integrated soil-bedrock column, which attenuates cosmic ray bombardment:

$\rho_{d>\text { soil }}=\left(\frac{d_{\text {soil }}}{d} \times \rho_{\text {soil }}\right)+\left(\frac{d-d_{\text {soil }}}{d} \times \rho_{\text {rock }}\right)$

Equation (2)

$d_{\text {soil }}$ is the depth of the soil-bedrock boundary (e.g. $100 \mathrm{~cm}$ in the initial case).

Under a given background surface erosion rate $\left(\varepsilon ; \mathrm{cm} \mathrm{yr}^{-1}\right)$, the nuclide concentration at depth, $d$, of the starting profile $\left(N_{t=0}\right.$; atoms $\left.\mathrm{g}^{-1}\right)$ in secular equilibrium is given by:

$N_{d, t=0}=\frac{P_{N}}{\left(\frac{\rho \varepsilon}{\Lambda}+\lambda\right)}$

Equation (3)

where $\lambda$ is the decay constant of ${ }^{10} \mathrm{Be}\left(\lambda=4.62 \times 10^{-7} \mathrm{yr}^{-1}\right)$. As with the production rate equation, $\rho=\rho_{\text {soil }}=1.4 \mathrm{~g} \mathrm{~cm}^{-3}$ for depths $0 \mathrm{~cm}<d<100 \mathrm{~cm}$ and $\rho=\rho_{d}>$ soil for depths $d>$ $100 \mathrm{~cm}$.

Inherent to the steady-state model starting condition is a soil production rate, and soil production rates at secular equilibrium must equal the specific background rock erosion rate assumed in the model (i.e. $5 \mathrm{~mm} \mathrm{kyr}^{-1}, 10 \mathrm{~mm} \mathrm{kyr}^{-1}$ ). We assume in our model (based on field observations of no or thin saprolite) that soils are produced directly from bedrock, and in this way, the bedrock mass loss rate, assuming $\rho=2.7 \mathrm{~g} \mathrm{~cm}^{-3}$, at rock erosion rates of $5 \mathrm{~mm} \mathrm{kyr} \mathrm{m}^{-1}$ and $10 \mathrm{~mm} \mathrm{kyr}^{-1}$ is $13.5 \mathrm{~kg} \mathrm{~m}^{-2} \mathrm{kyr}^{-1}$ and $27 \mathrm{~kg} \mathrm{~m}^{-2} \mathrm{kyr}^{-1}$, respectively. Converting this mass loss rate yields soil production rates of $\sim 10 \mathrm{~mm} \mathrm{kyr}^{-1}$ and $\sim 20 \mathrm{~mm} \mathrm{kyr}^{-1}$, respectively, assuming the average soil density of $\rho_{\text {soil }}=1.4 \mathrm{~g} \mathrm{~cm}^{-3}$. Such rates are consistent with soil production rates from other studies in the Tablelands, derived from ${ }^{10} \mathrm{Be}$ and uranium-series isotopic systems (Heimsath et al., 2001; Suresh et al. 2013). The consistency between background rock erosion rates and their soil-equivalent rates with soil production rates calculated independently confirms the likelihood of our assumption that soils in the Tablelands were in steady-state with respect to erosion and production prior to the onset of Aboriginal burning.

We calculate ${ }^{10} \mathrm{Be}$ nuclide concentrations at depth intervals of $0.02 \mathrm{~cm}(2 \mathrm{~mm})$ for a total depth of $500 \mathrm{~cm}$ (Supplementary Figure DR3a).

\section{Defining the effective erosion rate}

Once Aboriginal burning is introduced to the landscape, the resultant increased erosion rates perturb the equilibrium profile. We assume that Aboriginal burns were constantly set 1 year in every 5 years (Gott, 2005), and we estimate that erosion rates increase 30x during that year, an estimate obtained from the increase in sediment yield from a hillslope sediment plot after a light burn (Prosser, 1990); each model is also run with an estimated 50x erosion rate increase for 1 year in every 5 years, estimated from the same study, but from a hillslope sediment plot that was moderately burned (Prosser 1990). 
Superimposing this one-year spike in erosion rates on the background erosion rate, we calculate an effective rock erosion rate $\left(\varepsilon_{\text {eff }} ; \mathrm{cm} \mathrm{yr}^{-1}\right)$ for the landscape:

$\varepsilon_{\text {eff }}=(0.2 \times 30 \varepsilon)+(0.8 \times \varepsilon)$

Equation (4)

A

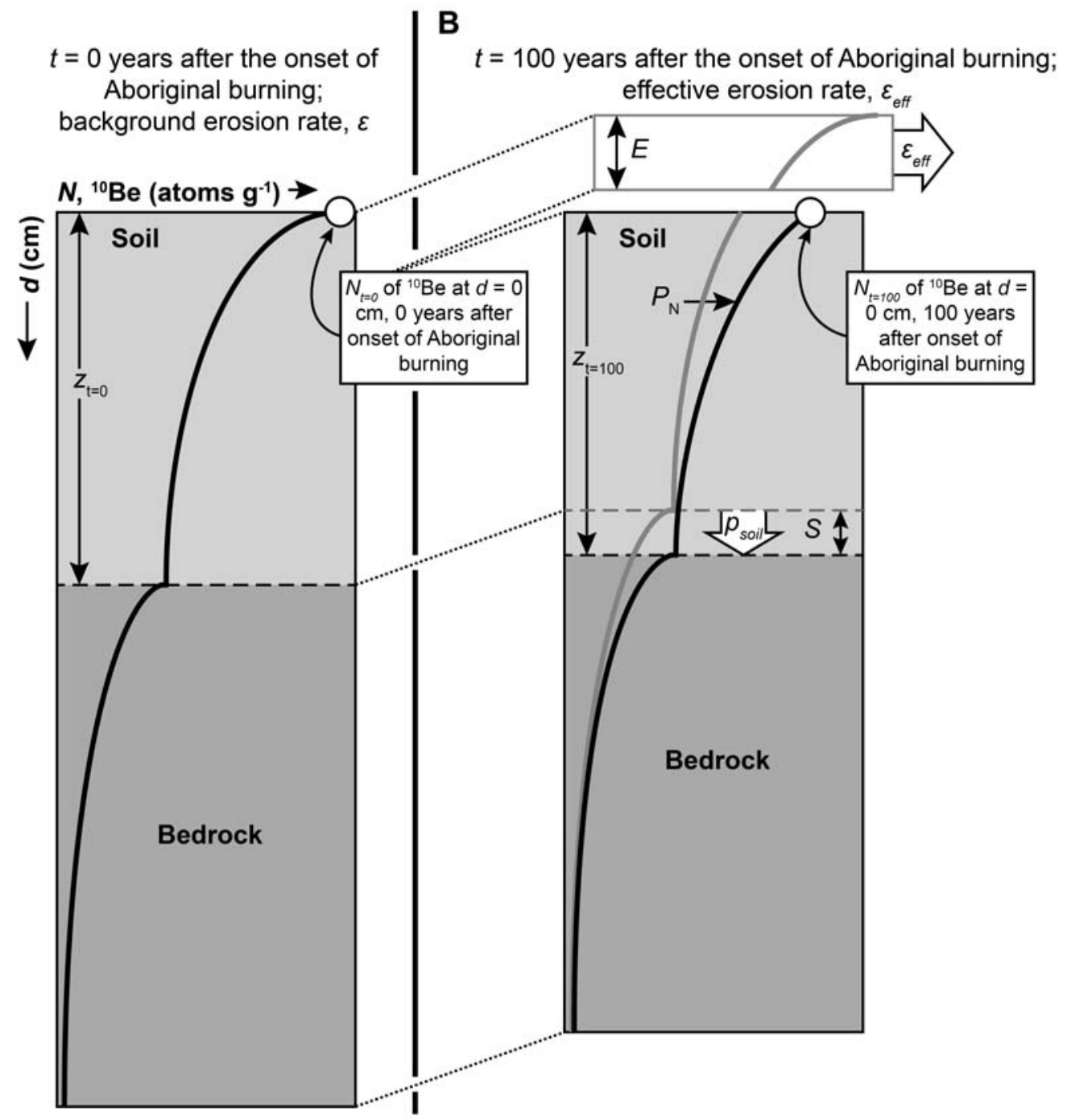

Supplementary Figure DR3. (A) ${ }^{10}$ Be concentrations $(N)$ in a Tablelands soil profile (solid black line) at secular equilibrium, assuming that erosion $(\varepsilon)$ is constant and Aboriginal burning had not yet become widespread $(t=0$ years). Soil-bedrock interface shown by dashed black line at depth $z_{t=0}$. (B) ${ }^{10} \mathrm{Be}$ concentrations $(N)$ in a Tablelands soil profile (solid black line; original nuclide profile, at time $t=0$, is shown by solid gray line) after the first modelled time step - in this case, 100 years after the onset of Aboriginal burning ( $t=100$ years). Because the effective erosion rate $\left(\varepsilon_{e f f}\right)$ is greater than the soil production rate $\left(p_{\text {soil }}\right)$, the soil-bedrock interface (dashed black line; former soil-bedrock interface, at time $t=0$, is shown by dashed grey line) becomes shallower in the profile $\left(z_{t=100}\right)$, relative to the surface $(d=0 \mathrm{~cm})$.

\section{Progressing the model}

We progress the model by 100 -year time steps in order to estimate the ${ }^{10} \mathrm{Be}$ concentration that we expect to measure in land surface material. We assume that the time elapsed between sediment erosion and sample collection is negligible, compared to the half- 
life of ${ }^{10} \mathrm{Be}(1.38 \mathrm{Myr})$; the concentration of ${ }^{10} \mathrm{Be}$ at the land surface is thus equivalent to the ${ }^{10} \mathrm{Be}$ we measure in fluvial sediment. Below, we detail the method and thought process behind the first 100-year time step of Aboriginal burning in our model, which can then be repeated for every subsequent 100 -year time step.

After the first 100 years of constant Aboriginal burning, $E \mathrm{~cm}$ of soil is eroded from the top of the model profile at a rate equal to the soil-density equivalent of the background rock erosion rate (Supplementary Figure DR3b):

$E=100 y r \times\left(\varepsilon_{\text {eff }} \times \frac{\rho_{\text {rock }}}{\rho_{\text {soil }}}\right)$

Equation (5)

For example, given a background rock erosion rate, $\varepsilon=5 \mathrm{~mm} \mathrm{kyr}^{-1}$, the effective rock erosion rate is increased by $30 \mathrm{x}$ the background erosion rate for 1 year in every 5 years, and so $\varepsilon_{\text {eff }}=$ $34 \mathrm{~mm} \mathrm{kyr}^{-1}$, which removes a soil thickness, $E$, at a rate of $66 \mathrm{~mm} \mathrm{kyr}^{-1}$, or $0.066 \mathrm{~mm} \mathrm{yr}^{-1}$. Thus, in each $100 \mathrm{yr}$ time step, $6.6 \mathrm{~mm}$, or $0.66 \mathrm{~cm}$ of soil is eroded.

At the same time, $S \mathrm{~cm}$ of soil is produced (Supplementary Figure DR3b):

$S=100 y r \times p_{\text {soil }}$

Equation (6)

where $p_{\text {soil }}$ is the soil production rate. We assume that the steady-state soil production rate in the initial model profile is not affected by Aboriginal burning and therefore, that the soil production rate remains equivalent to the background rock erosion rate. In the example of a 5 $\mathrm{mm} \mathrm{kyr}{ }^{-1}$ background rock erosion rate, $p_{\text {soil }}=5 \mathrm{~mm} \mathrm{kyr}^{-1}$, and thus in each 100 year time step $S=0.5 \mathrm{~mm}$, or $0.05 \mathrm{~cm}$ of soil is produced.

If soils in the Tablelands were thoroughly and constantly mixed throughout the entirety of each catchment for the whole ${ }^{10} \mathrm{Be}$ integration period, ${ }^{10} \mathrm{Be}$ concentrations at any depth in the soil column would equal the surficial ${ }^{10} \mathrm{Be}$ concentration and not change through time. We thus would not notice any effect of Aboriginal burning until all soils were eroded to bedrock. Certainly soils are partially mixed by bioturbation, locally in each catchment, but mixing only affects the uppermost part of soil profiles in the Tablelands (Muñoz-Salinas et al., 2014) and we observed little evidence in the field for pervasive or ubiquitous soil disturbance by burrowing mammals. The presence of well-formed soil structures existing throughout southeastern Australia (Bishop et al., 1980) is a further indication that soils are at most moderately turbated. For these reasons, soil mixing was not built into the model.

Neither do we account for the effects of fires ignited by natural causes (e.g. lightning) as the geomorphological effects of large-scale events with long recurrence intervals are averaged over the ${ }^{10} \mathrm{Be}$ erosion rate integration timescale. Sediment delivery by gully or rill erosion or debris flows is sometimes observed in steeper landscape settings after high intensity burns (Nyman et al., 2011; Sheridan et al., 2007); however, this model does not include such sediment delivery because there is more evidence to suggest that Aboriginal burns were light to moderate rather than severe, our sampled catchments are not steep, and most importantly, all sampled catchments are ungullied.

Considering ${ }^{10} \mathrm{Be}$ concentration during the first 100 years of Aboriginal burning, the nuclide inventory of the uppermost $E \mathrm{~cm}$ of sediment is removed, and soil that was once at depth $d=E \mathrm{~cm}$ at time $t=0$ years is now found at a depth $d=0 \mathrm{~cm}$ at time $t=100$ years after Aboriginal burning was introduced to the landscape. ${ }^{10} \mathrm{Be}$ is also produced in the 100 years since Aboriginal burns started, and its production at any depth is given by Equation (1). However, soil depth, $z$, is a function of $S$ and $E$, such that the soil depth after 100 years of Aboriginal burning $\left(z_{t=100}\right)$ is given by: 
In this way, if $E \neq S$, the depths for which $\rho_{\text {soil }}$ and $\rho_{d>\text { soil }}$ are valid in Equation (3) change in each time step. For example, after the first 100 years of Aboriginal burning, $\rho_{\text {soil }}$ becomes valid only for depths $0<d<z_{t=100}$ and $\rho_{d}>$ soil becomes valid for depths $d>z_{t=100}$.

We repeat and continue this process using 100-year time steps, and the surface concentration $(N$ at $d=0 \mathrm{~cm}$ ) is recorded at each time step for 300 time steps, which is equivalent to 30,000 years - a duration that exceeds the available archaeological record of Aboriginal occupation in the Tablelands (Flood et al., 1987; Stockton and Holland, 1974). Over time, we produce a plot of modelled surface ${ }^{10} \mathrm{Be}$ concentrations $(N$ at $d=0)$ versus the duration of time since Aboriginal burning was introduced to the Tablelands landscape. In our erosion models, $E$ is always greater than $S$, and so the soil thickness $(z)$ diminishes over time until eventually all soil is eroded and the nuclide concentration at the land surface reflects ${ }^{10} \mathrm{Be}$ eroded from bedrock rather than from soil. When all soils are eroded, $E$ becomes equivalent to the depth of rock removed by the background rock erosion rate in each 100 year time step and $S$ becomes negligible. This change in soil thickness in our model occurs because Aboriginal burning causes a one-off increase of the effective erosion rate during Aboriginal occupation of the Tablelands $(<30 \mathrm{kyr})-$ a rate that outpaces soil production and effectively strips the soil mantle. The Tablelands landscape is not a bedrock landscape; thus we only consider modelled surficial $N$ values if they are derived from soil, not bedrock, as plausible Aboriginal burning scenarios (Supplementary Figure DR2). We do not apply the model to bedrock outcrop erosion rates as outcrops only represent solitary points on the landscape.

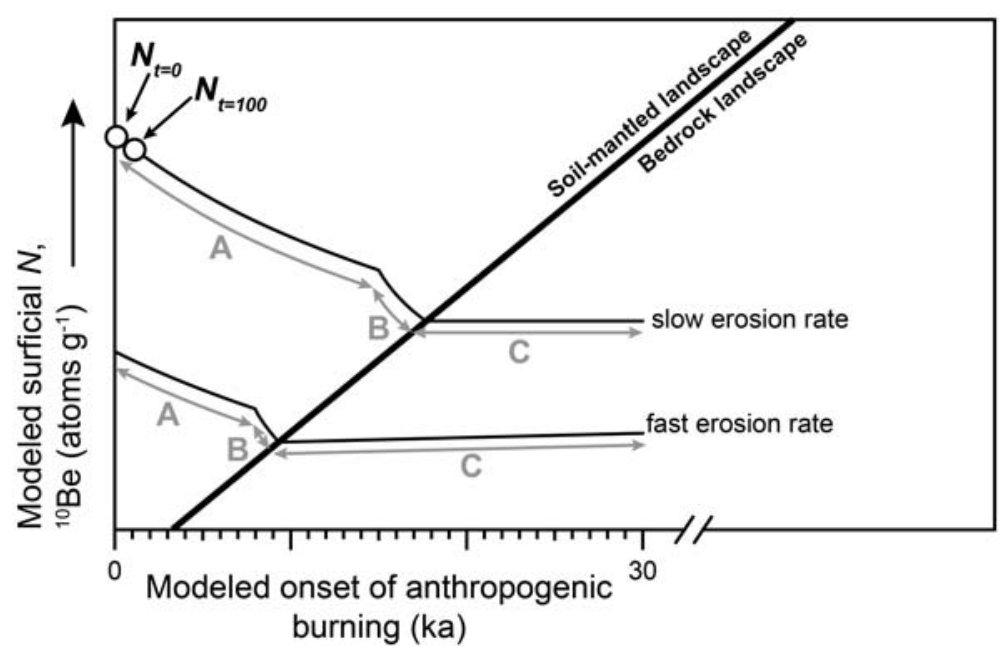

Supplementary Figure DR4. Modelled surficial concentrations of ${ }^{10}$ Be nuclides $(N)$ for each 100 year time step, given a constant background erosion rate $(\varepsilon)$. Model line segments labeled with A reflect the land surface nuclide concentration during erosion of the original $100 \mathrm{~cm}$ soil column; those labeled B reflect the land surface nuclide concentration during erosion of soil generated from bedrock originally below the initial $100 \mathrm{~cm}$ soil depth; those labeled $\mathrm{C}$ reflect the land surface nuclide concentration during erosion of bedrock once all soils have been stripped. The slope of the $\mathrm{C}$ lines becomes positive because nuclide production in the rock exceeds the nuclide loss by the erosion rate. White circles show detail of how the modelled $N$ curve is derived from each time step. 


\section{Sample collection strategy}

Landscape stability is assessed by comparing ${ }^{10} \mathrm{Be}$ erosion rates derived from fluvial sediment samples, collected from active streambeds and bars throughout the Tablelands $(n=$ $\left.11,1-190 \mathrm{~km}^{2}\right)$, to those derived from rock outcrops $(n=6)$. Gully incision into Tablelands valley bottoms occurred regionally after Europeans cleared the land of its open eucalyptus woodlands for livestock grazing (Portenga, 2015; Rustomji and Pietsch, 2007). Because gully incision can supply sediment to streams from deep sources that are thus less-dosed by neutrons and lower in ${ }^{10} \mathrm{Be}$, we sampled catchments with no or limited evidence of gully incision, determined by physical inspection of the catchments in the field and on satellite imagery. Given the relatively small catchment sizes, we assume that the sediment storage time between erosion and sample collection is minimal compared to the $1.38 \mathrm{Ma}{ }^{10} \mathrm{Be}$ halflife.

For the outcrop samples, a few centimeters of bedrock was removed from the tops of prominent outcrops collected throughout the Tablelands $(n=6)$ so that the dataset reflects regional outcrop erosion, unbiased toward a particular landscape feature. The outcrop features we sampled are inherently the slowest eroding parts of the landscape; therefore by comparing outcrop and fluvial sediment erosion rates, we supplement our knowledge of regional geomorphological stability over tens of millions of years (Bishop, 1985; Bishop and Goldrick, 2000) with an assessment of geomorphological stability over tens of thousands of years.

\section{Sample preparation and analysis}

All samples were processed at the University of Vermont (UVM) Cosmogenic Nuclide Laboratory in Burlington, Vermont, USA. Bedrock samples were crushed, ground using a plate grinder, and sieved to the $250-850 \mu \mathrm{m}$ grain size fraction to obtain mostly monomineralic particle sizes. Some soils in southeastern Australia have duplex structures, with a noticeable lack of fine grain sizes in the uppermost horizon, but since ${ }^{10} \mathrm{Be}$ concentrations in fluvial sediment are typically consistent across all grain size fractions in non-tropical settings (Bierman and Nichols, 2004), fluvial sediment samples were wet-sieved to the $250-850 \mu \mathrm{m}$ grain size fraction. In this way, the grain size fraction from which we measure ${ }^{10} \mathrm{Be}$ is appropriate for our study since our model only considers surficial erosion and not erosion of finer grain size fractions from the sub-surface. The $250-850 \mu \mathrm{m}$ grain size fractions of both crushed bedrock and fluvial sediment were magnetically separated and etched in a series of weak $\mathrm{HCl}$ and $\mathrm{HF} / \mathrm{HNO}_{3}$ baths in order to isolate quartz grains following standard methods and procedures (Kohl and Nishiizumi, 1992). A $250 \mu \mathrm{g}$ aliquot from acidetched samples was then tested for cation concentrations using inductively coupled plasmaoptical emission spectroscopy (ICP-OES, samples analyzed by P. Bierman). If levels of Al, $\mathrm{Ti}$, and Fe were $>150 \mathrm{ppm}$ or total cation abundances were $>300-400 \mathrm{ppm}$, the entire sample was treated with another week of weak-acid etches and tested again until the desired cation concentrations were met. Isolated quartz separates from each sample were weighed and $\sim 250$ $\mu \mathrm{g}$ of naturally-occurring ${ }^{9} \mathrm{Be}$ was added as carrier to each sample before quartz dissolution ( ${ }^{9}$ Be carrier, 285-2A was created at the UVM Cosmogenic Laboratory; $\rho=1.012 \mathrm{~g} / \mathrm{mL}$ ). Be was extracted following standard UVM procedures (Corbett et al., 2011). As the presence of undetected native ${ }^{9} \mathrm{Be}$ in samples can result in overestimations of erosion rates (Portenga et al., 2015), aliquots from each sample were measured to confirm that the only ${ }^{9} \mathrm{Be}$ in each sample was that added as a carrier; no samples contained excess ${ }^{9} \mathrm{Be}$. Be was separated from Fe using anion exchange resins and from $\mathrm{Al}$ and Ti by cation exchange resins, precipitated at $\mathrm{pH} 8$ as a hydroxide, dried and ignited to produce beryllium oxide, mixed with $\mathrm{Nb}$ at a $1: 1$ 
molar ratio, and packed into copper cathodes for measurement by accelerator mass spectrometry (AMS).

${ }^{10} \mathrm{Be} /{ }^{9} \mathrm{Be}$ ratios were measured using AMS at the Scottish Universities Environmental Research Centre (SUERC) in April 2014 (Xu et al., 2015). ${ }^{10} \mathrm{Be} /{ }^{9} \mathrm{Be}$ measurements were normalized to the NIST SRM4325 standard material, which has a nominal ratio of $2.79 \times 10^{-}$ ${ }^{11}$ and blank corrected using two process blanks (avg. $=3.67 \pm 0.085 \times 10^{-15}$ ), from which concentrations of ${ }^{10} \mathrm{Be}$ were determined for each sample (Table S2). ${ }^{10} \mathrm{Be} /{ }^{9} \mathrm{Be}$ ratios shown in Table S2 include AMS measurement uncertainties, and a 1.5\% additional AMS uncertainty, based on reproducibility and secondary standards in the AMS run for samples with similar ${ }^{10} \mathrm{Be} /{ }^{9} \mathrm{Be}$ ratios, was propagated throughout.

Erosion rates were calculated using the CRONUS erosion rate calculator (Balco et al., 2008). Bedrock erosion rates were calculated with no horizon shielding factors; however, shielding factors for fluvial sediment erosion rates were calculated using the weighted mean basin slope for each catchment (Table S1) (Dunne et al., 1999) derived from 30 m SRTM elevation. The effective elevation for drainage catchments - the elevation at which the average ${ }^{10} \mathrm{Be}$ production rate for the catchment is expected (Portenga and Bierman, 2011) was used along with the mean latitude and longitude of drainage catchments as CRONUS inputs for fluvial erosion rate samples.

\begin{tabular}{|c|c|c|c|c|c|c|c|c|c|c|c|}
\hline \multicolumn{12}{|c|}{ Supplementary Table DR1: ${ }^{10}$ Be Data } \\
\hline $\begin{array}{l}\text { UVM } \\
\text { Batch }\end{array}$ & $\begin{array}{c}\text { Sample } \\
\text { ID } \\
\end{array}$ & $\begin{array}{c}\text { SUERC } \\
\text { No. }\end{array}$ & \multicolumn{3}{|c|}{$\begin{array}{l}\text { Blank Corrected }^{a} \\
{ }^{10} \mathrm{Be} /{ }^{9} \mathrm{Be} \times 10^{-13}\end{array}$} & $\begin{array}{l}\text { Sample } \\
\text { mass }(\mathrm{g})\end{array}$ & $\begin{array}{c}\text { Carrier } \\
{ }^{9} \mathrm{Be}(\mu \mathrm{g})^{b}\end{array}$ & \multicolumn{3}{|c|}{$\begin{array}{c}{\left[{ }^{10} \mathrm{Be}\right]^{a}} \\
\left(\text { atoms g }{ }^{-1}\right) \times 10^{5}\end{array}$} & Uncertainty \\
\hline \multicolumn{12}{|c|}{ Fluvial sediment samples } \\
\hline 530 & TLB-01 & b8002 & 9.63 & \pm & 0.38 & 17.392 & 219.7 & 7.95 & \pm & 0.31 & $4.0 \%$ \\
\hline 530 & TLB-02 & b8003 & 13.88 & \pm & 0.54 & 19.9571 & 220.9 & 10.12 & \pm & 0.39 & $3.9 \%$ \\
\hline 530 & TLB-03 & b8004 & 12.90 & \pm & 0.47 & 19.9851 & 221.9 & 9.38 & \pm & 0.34 & $3.7 \%$ \\
\hline 530 & TLB-04 & b8005 & 3.16 & \pm & 0.18 & 10.6158 & 221.8 & 4.32 & \pm & 0.25 & $5.7 \%$ \\
\hline 532 & TLB-05 & b8017 & 8.76 & \pm & 0.19 & 20.1082 & 220.1 & 6.20 & \pm & 0.14 & $2.2 \%$ \\
\hline 530 & TLB-06 & b8007 & 11.73 & \pm & 0.37 & 19.9382 & 221.8 & 8.54 & \pm & 0.27 & $3.1 \%$ \\
\hline 530 & TLB-07 & b8008 & 10.90 & \pm & 0.48 & 20.0049 & 221.4 & 7.91 & \pm & 0.35 & $4.4 \%$ \\
\hline 532 & TLB-08 & b8021 & 5.83 & \pm & 0.14 & 20.3274 & 220.5 & 4.11 & \pm & 0.10 & $2.4 \%$ \\
\hline 532 & TLB-09 & b8022 & 8.21 & \pm & 0.19 & 20.0325 & 222.8 & 5.61 & \pm & 0.13 & $2.3 \%$ \\
\hline 532 & TLB-10 & b8023 & 8.03 & \pm & 0.23 & 20.0092 & 258.8 & 6.67 & \pm & 0.20 & $2.9 \%$ \\
\hline 532 & TLB-11 & b8024 & 7.90 & \pm & 0.18 & 20.2169 & 221.7 & 5.60 & \pm & 0.13 & $2.3 \%$ \\
\hline \multicolumn{12}{|c|}{ Outcrop samples } \\
\hline 530 & TLO-01 & b8009 & 9.98 & \pm & 0.40 & 19.8917 & 222.1 & 7.34 & \pm & 0.29 & $4.0 \%$ \\
\hline 530 & TLO-02 & b8010 & 3.76 & \pm & 0.24 & 10.9515 & 221.9 & 5.04 & \pm & 0.32 & $6.2 \%$ \\
\hline 530 & TLO-04 & b8011 & 23.79 & \pm & 1.09 & 19.9824 & 221.6 & 17.37 & \pm & 0.80 & $4.6 \%$ \\
\hline 530 & TLO-05 & b8014 & 1.91 & \pm & 0.39 & 20.1039 & 221.4 & 13.85 & \pm & 0.28 & $2.0 \%$ \\
\hline 532 & TLO-06 & b8020 & 7.99 & \pm & 0.18 & 7.4278 & 223.4 & 15.75 & \pm & 0.35 & $2.2 \%$ \\
\hline 530 & TLO-07 & b8015 & 13.24 & \pm & 0.58 & 19.6634 & 221.1 & 9.84 & \pm & 0.43 & $4.4 \%$ \\
\hline
\end{tabular}

${ }^{a}{ }^{10} \mathrm{Be} /{ }^{9} \mathrm{Be}$ were measured using accelerator mass spectrometry (AMS) at the Scottish Universities Environmental Research Centre (SUERC) and normalised to NIST SRM4325 with a nominal ratio of $2.79 \times 10^{-11}$ and blankcorrected using two process blanks (avg. $=3.67 \pm 0.85 \times 10-15)$ from which $10 \mathrm{Be}$ concentrations are derived. Uncertainties shown are AMS measurement uncertainties and a $1.5 \%$ additional uncertainty, propagated in quadrature.

${ }^{b}$ We added $\sim 220-260 \mu \mathrm{g}$ of ${ }^{9}$ Be carrier, made at UVM $\left(285-2 \mathrm{~A}, \rho=1.012 \mathrm{~g} \mathrm{~mL}^{-1}\right)$, to each sample before quartz dissolution. 
Supplementary Table DR2: Location Information \& Erosion Rates

\begin{tabular}{|c|c|c|c|c|c|c|c|c|c|c|c|c|}
\hline Sample & Sample Location & $\begin{array}{l}\text { Latitude } \\
\left({ }^{\circ} S\right)^{a}\end{array}$ & $\begin{array}{l}\text { Longitude } \\
\qquad\left({ }^{\circ} E\right)^{a}\end{array}$ & $\begin{array}{l}\text { Elevation } \\
\qquad(\mathrm{m})^{a}\end{array}$ & $\begin{array}{l}\text { Shielding } \\
\text { Factor }^{b}\end{array}$ & $\begin{array}{l}\text { Thickness } \\
(\mathrm{cm})\end{array}$ & $\begin{array}{c}\text { Erosion Rate } \\
\left(\mathrm{mm} \mathrm{kyr} \mathrm{r}^{-1}\right)^{c}\end{array}$ & $\begin{array}{l}\text { Area } \\
\left(\mathrm{km}^{2}\right)\end{array}$ & $\begin{array}{c}\text { Sed. Flux } \\
\left(\mathrm{Mg} \mathrm{km}^{-1} \mathrm{yr}^{-1}\right)\end{array}$ & Lith. $^{d}$ & $\begin{array}{c}\text { Basin } \\
\text { Relief }(\mathrm{m})\end{array}$ & $\begin{array}{l}\text { Weighted Mean } \\
\text { Basin Slope }\left({ }^{\circ}\right)^{b}\end{array}$ \\
\hline \multicolumn{13}{|c|}{ Fluvial sediment samples } \\
\hline TLB-01 & $\begin{array}{l}\text { Spring Flat Creek } \\
\text { (trib. to Back Cr.) }\end{array}$ & $\begin{array}{l}35.0618 \\
35.0780\end{array}$ & $\begin{array}{l}149.2132 \\
149.1770\end{array}$ & $\begin{array}{l}585 \\
644\end{array}$ & 1 & -- & $5.8 \pm 0.5$ & 45.0 & 8.11 & $\mathrm{Sa}, \mathrm{Si}, \mathrm{Ig}$ & 205 & 3 \\
\hline TLB-02 & $\begin{array}{l}\text { Bolong River } \\
\text { (Golspie Rd.) }\end{array}$ & $\begin{array}{l}34.2979 \\
34.3954\end{array}$ & $\begin{array}{l}149.6259 \\
149.6704\end{array}$ & $\begin{array}{l}754 \\
908\end{array}$ & 1 & --- & $5.3 \pm 0.5$ & 186.6 & 7.42 & $\mathrm{Gr}, \mathrm{Si}, \mathrm{Sa}$ & 271 & 3 \\
\hline TLB-03 & Collector Creek & $\begin{array}{l}34.9014 \\
34.8823\end{array}$ & $\begin{array}{l}149.4334 \\
149.4711\end{array}$ & $\begin{array}{l}692 \\
745\end{array}$ & 1 & -- & $5.2 \pm 0.5$ & 125.2 & 7.22 & $\mathrm{Si}$ & 197 & 2 \\
\hline TLB-04 & Deep Creek & $\begin{array}{l}35.3719 \\
35.3850\end{array}$ & $\begin{array}{l}149.2552 \\
149.2921\end{array}$ & $\begin{array}{l}589 \\
809\end{array}$ & 1 & --- & $13.0 \pm 1.2$ & 16.4 & 18.14 & Sa & 419 & 6 \\
\hline TLB-05 & $\begin{array}{c}\text { Humes Creek } \\
\text { (Biala-Gurrundah Road) }\end{array}$ & $\begin{array}{l}34.6394 \\
34.6062\end{array}$ & $\begin{array}{l}149.3744 \\
149.4027\end{array}$ & $\begin{array}{l}782 \\
873\end{array}$ & 1 & -- & $9.0 \pm 0.7$ & 53.1 & 12.56 & $\mathrm{Si}, \mathrm{Sa}, \mathrm{Ba}$ & 206 & 3 \\
\hline TLB-06 & $\begin{array}{c}\text { Kings Creek } \\
\text { (trib. to Tarlo R. at Backarm Rd.) }\end{array}$ & $\begin{array}{l}34.5386 \\
34.5416\end{array}$ & $\begin{array}{l}149.7427 \\
149.7335\end{array}$ & $\begin{array}{l}753 \\
788\end{array}$ & 1 & -- & $5.9 \pm 0.5$ & 0.8 & 8.26 & $\mathrm{Si}, \mathrm{Sa}$ & 87 & 3 \\
\hline TLB-07 & Meehans Creek & $\begin{array}{l}35.3197 \\
35.3559\end{array}$ & $\begin{array}{l}149.5620 \\
149.5531\end{array}$ & $\begin{array}{l}813 \\
983\end{array}$ & 1 & --- & $7.5 \pm 0.7$ & 11.9 & 10.54 & Gd & 388 & 8 \\
\hline TLB-08 & $\begin{array}{l}\text { Tributary to Jerrabomberra } \\
\text { Creek (at Swan Dr.) }\end{array}$ & $\begin{array}{l}35.4320 \\
35.4474\end{array}$ & $\begin{array}{l}149.1868 \\
149.1726\end{array}$ & $\begin{array}{l}712 \\
817\end{array}$ & 1 & --- & $13.8 \pm 1.1$ & 5.4 & 19.29 & $\mathrm{Rh}$ & 207 & 6 \\
\hline TLB-09 & Urila Creek & $\begin{array}{l}35.5355 \\
35.5817\end{array}$ & $\begin{array}{l}149.2991 \\
149.2841\end{array}$ & $\begin{array}{l}718 \\
951\end{array}$ & 1 & --- & $10.8 \pm 0.9$ & 37.4 & 15.12 & $\mathrm{Gd}, \mathrm{Sa}$ & 517 & 9 \\
\hline TLB-10 & $\begin{array}{l}\text { Wheeo Creek } \\
\text { (Narrawa Road) }\end{array}$ & $\begin{array}{l}34.4525 \\
34.4928\end{array}$ & $\begin{array}{l}149.2756 \\
149.3400\end{array}$ & $\begin{array}{l}762 \\
881\end{array}$ & 1 & -- & $8.3 \pm 0.7$ & 78.9 & 11.63 & $\mathrm{Si}, \mathrm{Sa}, \mathrm{Ba}$ & 257 & 3 \\
\hline \multirow[t]{2}{*}{ TLB-11 } & $\begin{array}{l}\text { Yandyguinula Creek } \\
\text { (Galvins Cr. Rd.) }\end{array}$ & $\begin{array}{l}35.4595 \\
35.4914\end{array}$ & $\begin{array}{l}149.5080 \\
149.5244\end{array}$ & $\begin{array}{l}809 \\
997\end{array}$ & 1 & -- & $11.1 \pm 0.9$ & 21.9 & 15.60 & $\mathrm{Gd}, \mathrm{Sa}$ & 449 & 9 \\
\hline & & & & Area & $\begin{array}{r}\text { Average } \\
\text {-weighted }\end{array}$ & $\begin{array}{l} \pm \text { Std } \mathrm{Err}= \\
\text { Average }=\end{array}$ & $\begin{array}{l}8.7 \pm 0.9 \\
7.0\end{array}$ & & & & & \\
\hline \multicolumn{2}{|c|}{ Outcrop samples } & & & & & & & & & & & \\
\hline TLO-01 & $\begin{array}{c}\text { Abbeyville } \\
\text { (along Bevendale Rd.) }\end{array}$ & 34.5108 & 149.2122 & 722 & 1 & 3 & $6.7 \pm 0.6$ & --- & -- & $\mathrm{Gr}$ & -- & -- \\
\hline TLO-02 & Big Monks Hill & 35.4832 & 149.1081 & 907 & 1 & 1 & $11.9 \pm 1.2$ & --- & --- & $\lg$ & -- & --- \\
\hline TLO-04 & Galvins Creek Road & 35.4598 & 149.5188 & 891 & 1 & 1 & $2.9 \pm 0.3$ & --- & --- & $\mathrm{Gd}$ & --- & -- \\
\hline TLO-05 & Gundaroo Road & 34.8769 & 149.2470 & 712 & 1 & 7 & $3.1 \pm 0.3$ & --- & -- & $\mathrm{Gr}$ & -- & -- \\
\hline TLO-06 & Old Joe Hill & 35.1939 & 149.1908 & 808 & 1 & 5 & $2.9 \pm 0.3$ & --- & --- & $\lg$ & -- & -- \\
\hline \multirow[t]{2}{*}{ TLO-07 } & $\begin{array}{l}\text { Winrock Estate } \\
\text { (along Oolong Rd.) }\end{array}$ & 34.7818 & 149.1647 & 614 & 1 & 4 & $4.3 \pm 0.4$ & -- & -- & $\mathrm{Gr}$ & -- & -- \\
\hline & & & & & Average & \pm Std Err $=$ & $5.3 \pm 1.4$ & & & & & \\
\hline
\end{tabular}

a For TLB samples, average basin coordinates and effective basin elevation are shown in gray. The elevation is an effective elevation derived by summarising ${ }^{10} \mathrm{Be}$ production for the whole basin at the mean coordinates and solving for the elevation required to yield the calculated ${ }^{10} \mathrm{Be}$ production (Portenga and Bierman, 2011).

${ }^{b}$ Shielding factors are estimated using shielding correction factors (Portenga et al., 2015) using the mean weighted basin slope derived from 30-meter SRTM elevation datasets

${ }^{c}$ Erosion rates are calculated using the CRONUS on-line cosmogenic erosion rate calculator (Wrapper script vers. 2.2, main calculator vers. 2.1, objective function vers. 2.0,

constants vers. 2.2.1, muons vers. 1.1) (Balco et al., 2008), accessed on 10 September 2014 using Lal's/Stone's scaling factors $(29,46)$ for spallogenic ${ }^{10}$ Be production.

CRONUS uses reference sea-level and high latitude spallogenic production rates of $4.49 \pm 0.39$ atoms $\mathrm{g}^{-1} \mathrm{yr}^{-1}( \pm 1 \sigma)$ and incorporates muogenic production. For CRONUS data-entry purposes, a bulk rock density of $2.7 \mathrm{~g} \mathrm{~cm}^{-3}$ were assumed and sample thicknesses of $1 \mathrm{~cm}$ were used for calculating basin-averaged basin-averaged erosion rates. Standard pressure flags and NIST_27900 standardisation for ${ }^{10} \mathrm{Be}$ were used.

${ }^{d}$ Lithologic abbreviations: Ba - Basalt, Gr - Granite, Gd - Granodiorite, Ig - Ignimbrite, Rh - Rhyolite, Sa - Sandstone, Si - Siltstone 


\section{References}

Balco, G., Stone, J. O., Lifton, N. A., and Dunai, T. J., 2008, A complete and easily accessible means of calculating surface exposure ages or erosion rates from ${ }^{10} \mathrm{Be}$ and ${ }^{26} \mathrm{Al}$ measurements: Quaternary Geochronology, v. 3, no. 3, p. 174-195.

Bierman, P., and Nichols, K., 2004, Rock to sediment - slope to sea with 10-Be - Rates of landscape change: Annual Review of Earth and Planetary Sciences, v. 32, p. 215-255.

Bishop, P., 1985, Southeast Australian late Mesozoic and Cenozoic denudation rates: A test for late Tertiary increases in continental denudation: Geology, v. 13, no. 7, p. 479482.

Bishop, P., and Goldrick, G., 2000, Geomorphological evolution of the East Australian continental margin, in Summerfield, M. A., ed., Geomorphology and Global Tectonics: Chichester, UK, John Wiley, p. 227-255.

Bishop, P., Mitchell, P. B., and Paton, T. R., 1980, The formation of duplex soils on hillslopes in the Sydney Basin, Australia: Geoderma, v. 23, p. 175-189.

Corbett, L. B., Young, N. E., Bierman, P. R., Briner, J. P., Neumann, T. A., Rood, D. H., and Graly, J. A., 2011, Paired bedrock and boulder ${ }^{10} \mathrm{Be}$ concentrations resulting from early Holocene ice retreat near Jakobshavn Isfjord, western Greenland: Quaternary Science Reviews, v. 30, no. 13-14, p. 1739-1749.

Dunne, J., Elmore, D., and Muzikar, P., 1999, Scaling factors for the rates of production of cosmogenic nuclides for geometric shielding and attenuation at depth on sloped surfaces: Geomorphology, v. 27, no. 1-2, p. 3-11.

Fifield, L. K., Wasson, R. J., Pillans, B., and Stone, J. O. H., 2010, The longevity of hillslope soil in SE and NW Australia: Catena, v. 81, no. 1, p. 32-42.

Flood, J., David, B., Magee, J., and English, B., 1987, Birrigai: A Pleistocene site in the south-eastern highlands: Archaeology in Oceania, v. 22, p. 9-26.

Gott, B., 2005, Aboriginal fire management in south-eastern Australia: aims and frequency: Journal of Biogeography, v. 32, p. 1203-1208.

Heimsath, A. M., Chappell, J., Dietrich, W. E., Nishiizumi, K., and Finkel, R. C., 2001, Late Quaternary erosion in southeastern Australia: A field example using cosmogenic nuclides: Quaternary International, v. 83-85, p. 169-185.

Heimsath, A. M., Chappell, J., Finkel, R. C., Fifield, K., and Alimanovic, A., 2006, Escarpment erosion and landscape evolution in southeastern Australia: Geological Society of America Special Paper, v. 398, p. 173-190.

Heimsath, A. M., Chappell, J., Spooner, N. A., and Questiaux, D. G., 2002, Creeping soil: Geology, v. 30, no. 2, p. 111-114.

Kohl, C. P., and Nishiizumi, K., 1992, Chemical isolation of quartz for measurement of insitu-produced cosmogenic nuclides: Geochimica et Cosmochimica Acta, v. 56, p. 3583-3587.

Lal, D., 1991, Cosmic ray labeling of erosion surfaces: In situ nuclide production rates and erosion models: Earth and Planetary Science Letters, v. 104, no. 2-4, p. 424-439.

Muñoz-Salinas, E., Bishop, P., Sanderson, D., and Kinnaird, T., 2014, Using OSL to assess hypotheses related to the impacts of land use change with the early nineteenth century arrival of Europeans in southeastern Australia: an exploratory case study from Grabben Gullen Creek, New South Wales: Earth Surface Processes and Landforms, v. 39, p. 1576-1586.

Nyman, P., Sheridan, G. J., Smith, H. G., and Lane, P. N. J., 2011, Evidence of debris flow occurrence after wildfire in upland catchments of south-east Australia: Geomorphology, v. 125, p. 383-401. 
Portenga, E. W., 2015, Assessments of Human Land Use, Erosion, and Sediment Deposition in the Southeastern Australian Tablelands [Ph.D thesis]: Glasgow, UK, University of Glasgow \& Macquarie University, 200 p.

Portenga, E. W., and Bierman, P. R., 2011, Understanding Earth's eroding surface with ${ }^{10} \mathrm{Be}$ : GSA Today, v. 21, no. 8, p. 4-10.

Portenga, E. W., Bierman, P. R., Duncan, C., Corbett, L. B., Kehrwald, N. M., and Rood, D. H., 2015, Erosion rates of the Bhutanese Himalaya determined using in situ-produced ${ }^{10}$ Be: Geomorphology, v. 233, p. 112-126.

Prosser, I. P., 1990, Fire, humans, and denudation at Wangrah Creek, southern Tablelands, N.S.W.: Australian Geographical Studies, v. 28, no. 1, p. 77-95.

Rustomji, P., and Pietsch, T., 2007, Alluvial sedimentation rates from southeastern Australia indicate post-European settlement landscape recovery: Geomorphology, v. 90, no. 12, p. 73-90.

Sheridan, G. J., Lane, P. N. J., and Noske, P. J., 2007, Quantification of hillslope runoff and erosion processes before and after wildfire in a wet Eucalyptus forest: Journal of Hydrology, v. 343, p. 12-28.

Stockton, E.D., and Holland, W., 1974, Cultural sites and their environment in the Blue Mountains: Archaeology and Physical Anthropology in Oceania, v. 9, p. 36-65.

Stone, J. O., 2000, Air pressure and cosmogenic isotope production: Journal of Geophysical Research, v. 105, no. B10, p. 23,753-723,759.

Suresh, P. O., Dosseto, A., Hesse, P. P., and Handley, H. K., 2013, Soil formation rates determined from Uranium-series isotope disequilibria in soil profiles from the southeastern Australian highlands: Earth and Planetary Science Letters, v. 379, p. 2637.

Wasson, R. J., Annual and decadal variation of sediment yield in Australia, and some global comparisons, in Proceedings Canberra Symposium, Canberra, 1994, Volume no. 224, IAHS, p. 269-279.

$\mathrm{Xu}$, S., Freeman, S. P. H. T., Rood, D. H., Shanks, R. M., 2015, Decadal ${ }^{10} \mathrm{Be},{ }^{26} \mathrm{Al}$, and ${ }^{36} \mathrm{Cl}$ QA measurements on the SUERC accelerator mass spectrometer: Nuclear Instruments and Methods B: Beam Interactions with Materials and Atoms. DOI:

10.1016/j.nimb.2015.03.064. 